\title{
The Management of Environmental Resources in the Construction Sector: An Empirical Model
}

\author{
Ionel-Sorinel Vasilca ${ }^{1}$, Madlena Nen ${ }^{2}$, Oana Chivu ${ }^{3}$, Valentin Radu ${ }^{4}{ }^{\mathbb{D}}$, Cezar-Petre Simion ${ }^{1}$ \\ and Nicolae Marinescu ${ }^{5, *}$ (D) \\ 1 Department of Management, Bucharest University of Economic Studies, 010374 Bucharest, Romania; \\ Vasilcaionel18@stud.ase.ro (I.-S.V.); cezar.simion@man.ase.ro (C.-P.S.) \\ 2 DLSSMM, Military Technical Academy Ferdinand I, 050141 Bucharest, Romania; madlena.nen@mta.ro \\ 3 Department of Materials, Polytechnic University of Bucharest, 060042 Bucharest, Romania; \\ Oana.virlan@upb.ro \\ 4 Department of Accounting and Finance, Valahia University of Targoviste, 130004 Targoviste, Romania; \\ valentin.radu@valahia.ro \\ 5 MTSAI Department, Transilvania University of Brasov, 500036 Brasov, Romania \\ * Correspondence: marinescu@unitbv.ro; Tel.: +40-722-533912
}

check for updates

Citation: Vasilca, I.-S.; Nen, M.; Chivu, O.; Radu, V.; Simion, C.-P.; Marinescu, N. The Management of Environmental Resources in the Construction Sector: An Empirical Model. Energies 2021, 14, 2489. https://doi.org/10.3390/en14092489

Academic Editor: Sergio Ulgiati

Received: 1 April 2021

Accepted: 26 April 2021

Published: 27 April 2021

Publisher's Note: MDPI stays neutral with regard to jurisdictional claims in published maps and institutional affiliations.

Copyright: (C) 2021 by the authors. Licensee MDPI, Basel, Switzerland. This article is an open access article distributed under the terms and conditions of the Creative Commons Attribution (CC BY) license (https:/ / creativecommons.org/licenses/by/ $4.0 /)$.

\begin{abstract}
This research emphasizes the analysis and assessment of the environmental impact in the construction sector. It aims to propose a model for analyzing the management of environmental resources in the building process. This specific sector presents a significant potential risk of negatively affecting the environment, through pollution, energy consumption, and waste generation. Environmental responsibility involves analyzing the environmental impact and implementing effective solutions for an adequate governance of the environmental resources. Various life cycle assessment methods are employed to design a new model of management of environmental resources, starting from the factors impacting the environment. The resulting model takes these factors into account and carries several advantages from an organizational point of view. One novel result is that the model can be applied at a microeconomic level as well as at a macroeconomic level. By implementing this model, the preconditions for reconfiguring operational conditions and processes with significant impact on resource consumption within construction projects can be created at a company level. As such, the objective for the construction sector is to manage the use of resources efficiently and, at the same time, to restore the areas possibly affected by the specific operations.
\end{abstract}

Keywords: construction; environment; environmental management; environmental resources; energy consumption; life cycle assessment

\section{Introduction}

The construction industry is deemed one of the major sources of environmental damage in the world [1]. The building process is not environmentally friendly by its sheer nature, starting from the supply of materials, continuing with the resources that are consumed, and ending with the overall effects on the surrounding environment. Its environmental impact has become highly relevant.

At a worldwide level, construction is responsible for about $50 \%$ of carbon emissions, $20-50 \%$ of consumption of natural resources, and $50 \%$ of total solid waste. Most of this occurs during the operational stage, causing a significant environmental impact [2,3]. The construction sector has an enormous influence on the environment and on the resources available. Moreover, it causes environmental harm, specifically air, soil, and water pollution. As a consequence, the need to mitigate such impact is stringent.

In recent times, more and more studies try to integrate sustainable practices into the construction process. As a general rule, opinions converge about the most important sources of environmental impact, such as the consumption of energy and resources, 
polluting emissions, waste disposal, adverse influence on biodiversity, as well as social disturbances and risk of accidents [4-6]. Furthermore, construction has become an important pillar in many national economies, driving energy consumption, emissions, and social impact to a higher level [7].

It was demonstrated empirically that energy consumption in the construction industry might represent even $40 \%$ of the overall energy demand in a developed country [8]. The role of buildings in addressing climate change issues becomes highly important due to their role in the total volume of greenhouse gas emissions and the increasing domestic energy consumption at global level [9].

When combining life cycle assessment (LCA) methods used with energy consumption during construction, Sartori and Hestnes (2007) found a linear relationship between the operating and the total energy demand by aggregating results from a total of 60 cases of buildings in nine countries [10]. The different components of energy also play an important part in the life cycle. According to Optis and Wild (2010), the embodied energy can reach up to $51 \%$, the operational energy even up to $97 \%$, while disposal energy just 3\% [11].

As such, employing eco-friendly and energy-saving construction methods can be a valuable method for saving fossil fuels and reducing emissions of greenhouse gas. The current period sees a substantial growth in the significance awarded to the energy used during the construction process, a step that was taken into account earlier in energycertification procedures.

The long-term success of a construction company implies the adoption of a sustainable business strategy that meets its objectives and the expectations of the shareholders, but at the same time aims to protect and preserve the natural resources that are left as a perpetual inheritance for future generations [12-14]. It is a fact that the environmental dimension has become a prerequisite element in the strategy of successful companies in the long run [15], even if the result on investment efficiency has not been completely assessed as positive [16].

Through its managerial activities of continuously improving processes, a construction business aims to satisfy customers' needs, preserve sound commercial relationships with partners, and establish trust with stakeholders. As stakeholders we can consider: the owners, the managers, the employees, the customers, the suppliers, the business partners, the local community, the media, and the society as a whole [17-20].

From a sustainability point of view, the management of the company is responsible for setting up the internal standards of compliance with environmental requirements, in line with the national legislation in the environmental field. Some opinions in the literature suggest that applying such standards is facing many challenges, while education and training of personnel to correctly understand and implement these standards could be initially deemed costly for companies [21]. Research finds that environmental managers are destined to play a crucial part in advancing the environmental responsibility and sustainability in their respective businesses [22]. As such, it is imperative to raise the awareness of project managers concerning the environmental impact in the construction process [23].

This research contributes to the literature on responsibility and management of environmental resources in the construction sector. Following a thorough analysis of the models to date, it proposes a novel approach through a model that shares some elements with existing methods in the literature, but nevertheless features several advantages. The research focuses on some specific elements of environmental resources management to the detriment of other elements such as cost (materials, human resources, transport, etc.), productivity, profitability, or business ethics. This approach was chosen to determine a particular model to identify the specific environmental impact of the construction sector. The model can be applied for environmental assessment in construction at the microeconomic level, as well as at the macroeconomic level, using a summative approach.

The research is structured in the following sections. Next, the literature review highlights some of the most important propositions regarding models of analysis for responsibility and governance of environmental resources in the construction sector. The third section 
presents the methodology of the research. A model for the responsibility of environmental resources in the construction sector is developed in the fourth section. The concluding section discusses the results of the model and highlights the contribution of this study to the existing literature in the field.

\section{Literature Review}

There are several approaches to the models of responsibility analysis and management of environmental resources in the construction sector in the specialized literature. Among the most used in the research carried out so far are models based on the dynamics of environmental governance and involving transversal transaction costs; new business models that incorporate management of environmental resources; adaptations of cost-benefit analysis in the field of environmental performance; environment-cost-time optimization methods (including those based on genetic algorithms), models based on life cycle assessment (LCA) use; specific corporate social responsibility (CSR) models that integrate environmental resources.

Several research papers in the literature consider that environmental governance has its own dynamics that may have micro or macroeconomic explanations. Bolognesi and Nahrath (2020) use the concept of Transversal Transaction Costs (TTC) as a significant trigger of management failures. They show that TTC plays an essential role in restricting the possibility of environmental governance to manage the use of natural resources. Their research has also demonstrated that environmental management is confined to an Institutional Complexity Trap (ICT) that explains some of the failures in coordinating the use of natural resources [24].

Mokhlesian and Holmen (2012) highlight that the involvement in the development of sustainable buildings will determine companies in the field to reconfigure their business models regarding the following elements: capability, value configuration, partner network, value proposition, and cost structure [25]. The idea of reconfiguring business models and processes as a result of the impact of changing resource use models is also emphasized by Isik et al. (2010) and Jang et al. (2019) [26,27].

The resources challenge is one of the first conditions the business models adopted by companies in the field of construction need to face. In the case of construction companies, business internationalization is correlated with the degree of engagement of the company in environmental protection activities [28].

The results of the research in the aforementioned studies are explainable because the new business models adopted in the field of construction must incorporate the relationship with the stakeholders of a legal and institutional nature (the legal regulations in the field of the environment) and with the new values of the customers in the markets in which they exist and the demand for new projects, which includes more attention paid to environmental issues.

Shen et al. (2019) have adapted the cost-benefit analysis by customizing it to analyze the cost-effectiveness and environmental benefits. This model considers the costs and benefits regarding the following elements: energy consumption, water conservation, construction waste, attrition rate of steel and concrete. The application of the elaborated model was realized in the field of prefabricated construction [29].

Other models only partially consider a number of environmental protection issues. Feng et al. (2018) developed a comprehensive environment + cost + time optimization method for construction companies taking into account the effects of global warming. Their method allows taking into account the environmental protection aspects in project planning in an optimization model together with two essential parameters in project planning (cost and time) aimed at facilitating the decision-making processes of the contractors in the field of construction [30].

The typical approach for environmental impact assessment is the life cycle assessment (LCA), according to research conducted by Ding (2008) [31]. Buyle et al. (2013) perform a comprehensive review of LCA models used in the construction sector, both in the legislative 
framework that regulates this field of activity and the case studies found in the academic literature [32]. An LCA is one of the most recognized and used models for evaluating the environmental performance of the building process and operations.

Most such assessments consider that four steps are required for LCA: the definition of goals, analysis of inventory, impact assessment, and improvement valuation. Life cycle assessment generally follows the knowledge that the impact of the building sector on the surrounding environment focuses on the following elements: greenhouse effect or global warming, acidification, eutrophication, photochemical smog, depletion of resources, and eco-toxicity $[33,34]$.

However, Ortiz et al. (2009) extend the main effects of the construction process on the environment related to the LCA perspective to include excessive consumption of energy and creation of waste [35]. Eun et al. (2009) consider that the impact of construction on the environment may be best relevant to high energy consumption and waste of materials, generation of dust, air, and water pollution, as well as various toxic wastes produced during the construction process [36].

The use of life cycle assessment in the field of construction has led to the customization of the method according to the purpose of the research carried out. Li et al. (2010) proposed an evaluation model based on LCA. Applying this model led to the conclusion that reducing the dust generated from construction, reuse of water, and minimizing concrete waste were the most important means of reducing the environmental impact of the categories of works analyzed [37].

Bilec et al. (2006) conducted a holistic analysis of the environmental impact of construction work processes by applying a hybrid variant of LCA [38]. Sandanayake et al. (2018) used LCA in an attempt to analyze the environmental impact in different geographical areas (focused on air emission impact assessment). In this research, five major impact categories were ranked related to construction activities: global warming, acidification, eutrophication, photochemical oxidation, and human toxicity. These impact categories were then compared at the international, regional, and national level [39].

Researchers in the literature consider that LCA has a sequential approach to sustainability, lacking the economic and social aspects of sustainability [40]. In their view, LCA should be part of a complex of methods that includes various approaches to a sustainability assessment in the construction sector: environmental impact assessment, environmental and social impact assessment, strategic environmental assessment, technology assessment, and LCA.

To reduce some of the limitations of LCA-based approaches, Ozcan-Deniz et al. (2011) introduced an approach based on genetic algorithms of the time-cost-environment relation in the realization of the construction projects taking into account the environmental aspects [41].

Several models, such as that of Chegut et al. (2019) integrate environmental aspects into the broader innovation processes by analyzing the marginal cost for green buildings. The erection of green buildings assimilating some results of research, development, and innovation in the field brings significant effects on the overall impact of construction. Their research shows that the energy efficiency of buildings plays an important role in reducing carbon externalities [42]. Other research considers the effects of construction on air quality [43].

For the management of environmental resources in the construction sector, an important role is played by spatial planning, which can include both opportunities and barriers. The spatial plan embodies the policy in the field of urban planning. All buildings, refurbishment or retrofitting and landscape or infrastructures have to comply with rules and models present in spatial plans [44]. Among the opportunities offered by spatial plans for the management of environmental resources in the construction sector are enhancing and protecting natural resources and natural heritage; reducing environmental damage; developing energy resources while maintaining safety [45]. However, in the study conducted by Fontao (2020) it was concluded that the rules established by the spatial plan for seven 
cities in Portugal do not concern energy or water conservation in buildings. Moreover, the rules established by spatial plans do not promote sustainable buildings [44]. Other authors consider that a complete realization of the concept of a universally designed, healthy city requires a comprehensive public space management plan [46]. Spatial planning can also act as an important factor for low-carbon development objectives [47].

Some models of analysis of environmental resources in the construction sector are those specific to CSR that integrate environmental problems (including those of resource consumption) in the overall social responsibility of construction companies. Xia et al. (2018) based on the selection and systematic analysis of 68 articles and scientific communications dedicated to the topic of CSR in the field of construction, published between 2000 and 2017, concluded that there is a link between CSR and sustainable development in the field of construction [48]. This link can materialize in a number of areas where CSR can contribute to achieving the goals of sustainable development: changes in traditional procurement procedures, improvement of legislation in the field of environmental protection, integration of environmental aspects in the approach of CSR by small and medium-sized enterprises in the construction field. Improvement of legislation in the field of environmental protection may include some optimal directions of legal changes:

- Supplementing the annexes to Directive 2014/52/EU on the assessment of the effects of certain public and private projects on the environment with real estate development projects and projects of new residential complexes with a built-up area of more than 20,000 sqm;

- $\quad$ Completing the EU Criteria for Office Building Design, Construction, and Management with a clearer definition of comprehensive criteria regarding the project management of building contracts that have met or exceeded the environmental performance requirements set by the customer with the minimum level of environmental performance requirements required by the customer regarding the following aspects: installation and commissioning of building energy systems, site waste management, incorporation of recycled content;

- Expanding practices at a national or European level and creating global sustainable building codes to promote minimum standards of sustainable construction.

All these changes will face a number of obstacles. Supplementing the annexes to Directive 2014/52/EU on the assessment of the effects of certain public and private projects on the environment and completing the EU Criteria for Office Building Design, Construction, and Management will meet the opposition of real estate developers, customers of projects in development, but also to some of the builders. Furthermore, the adoption and implementation of globally valid sustainable building codes will encounter opposition from some member states regarding their implementation at a national level.

\section{Materials and Methods}

Environmental impact assessment is a systematic approach entirely in line with national environmental legislation. Its goal is to put activities with important environmental effects under the scrutiny of an environmental impact assessment process. This process tries to measure the environmental impact of several construction and production activities, under various conditions that may occur in the mid-term and in the long-term. Tiwari et al. (2016) performed a comprehensive review of environmental impact assessment methods in construction projects [49].

As concerns for sustainable development in the construction sector mount, alternative methods are developed by companies so as to diminish the environmental impact of buildings. The life cycle cost (LCC) approach is such a method and maybe the most efficient one for measuring the cost of designing a building. By employing the LCC method, the building's design can be integrated into the whole construction process. It is also helpful for identifying the possibilities to achieve efficient energy consumption, the best lighting method, and optimum heating, ventilation, and air conditioning layout. The aim is to arrive at the lowest overall costs possible. LCC is a complex action as it takes 
many variables into consideration, practically all categories of expenses associated with the stages of the building process.

Estimating the cost for different options of a construction project would carry a practical meaning for potential investors to choose one particular building project among various others. For example, even if one project means a high preliminary cost, after starting the operational stage, the comparative cost may be essentially smaller, due to reduced energy consumption [50].

The life cycle management combines three different viewpoints: the one of the manager, on how to integrate environmental aspects into decision-making; another, of the engineer, on how to reduce the environmental impact of the operations; and the last, of the leader, on how to develop a lasting organizational culture [51].

Life cycle assessment (LCA) and life cycle cost (LCC) relate to the complete construction process. The two methods may be employed together in practice to generate a better outcome that encompasses both the potential life cost and the potential environmental impact. Their combined use has the benefit of

- Choosing an optimum technical solution;

- Identifying a technical solution that meets the required environmental targets at the lowest cost;

- Calculating the environmental impact costs;

- Making an investment appraisal [52].

Indeed, the LCA method has not been employed on a large scale for newer models of eco-friendly buildings among managers in the construction sector. Asdrubali et al. (2013) investigated three different types of buildings, including all the life-cycle stages, starting with the supply of the building materials, to logistics and assembly during the operational phase, until the final stage of all elements. They found that the operational phase has a major impact on the whole process (77\% to $85 \%)$, while the influence of the building stage reaches only from about $14 \%$ to $21 \%$ [53].

Sharma et al. (2011) also contrasted the environmental impact of various buildings in their construction phase, concluding that LCA may be an essential tool, especially for buildings that strive to be energy-autonomous [54]. The use of LCA techniques in the design of new buildings has immense potential to achieve energy savings. Zabalza et al. (2013) designed an energy saving by fostering the development of life cycle assessment in buildings method, based on LCA for usage in an entire planning process. The method has been developed as a means to enhance the environmental performance of constructions and to serve as an energy savings measurement tool for project managers responsible for the various phases of the building process [55].

However, even if the qualitative approach is the most popular one in identifying and analyzing the pollution and risks generated, it should be accompanied by quantitative tools coupled with measurement indicators so as to control the impact along the construction stages. One such quantitative method for incorporating environmental aspects in constructions through a system of environmental indicators was developed by Borja et al. (2018) [56]. According to Gangolells et al. (2013), there is a limited number of studies that focus on the control of environmental performance during the construction stage and the integration of an environmental management system with a quantitative construction management system [57].

Some authors managed to develop a set of criteria for the adoption of sustainable management practices in the building sector, aimed at decreasing the environmental impact generated during the construction phase [58].

Predicting and monitoring the major environmental impact of construction, together with designing a prevention mechanisms, are essential for the building activity [59] and for the effectiveness of the environmental management system [60]. Furthermore, most of the impact can be controlled and mitigated by the project manager during the pre-construction phase [61], thus improving the sustainability of the building process. 
Moreover, a quantitative measurement of the environmental impact of a building in the works can help managers identify the main environmental impact elements and design ecological construction planning in the initial phase of the building.

This is especially important, as the building sector has a large contribution to the pollution of the environment, significant consumption of energy and generation of solid waste. Unfortunately, there is no coherent framework for the use of the disposed waste, which harms the environment, contributes to rising energy consumption, and depletes landfills [62]. Currently, the construction process is focused on using concrete, steel, and masonry as the most important building materials. Such materials generate a profound environmental impact, especially because demand and production are carried out on a large scale. Energy and water, among different resources and materials, are consumed in the construction process by temporary facilities. A study by Enshassi (2014) revealed no less than 47 environmental impacts of construction projects. Among these, the consumption of resources stood out as the main impact affecting the environment [63].

As a result of competitive development, businesses are designed to strike a balance between environment and economic performance. Thanks to the use of logistic management processes, waste streams in their processes have become more cost-effective. Application of solutions proposed by authors who used mathematical formulas which allowed them to estimate the cost of logistics in industrial waste management led to significant improvements in this area [64].

Some authors are analyzing the environmental impact by using specific indicators of the environment to ensure that a business benefits from a dynamic and efficient navigation system which, at the same time, may act as a milestone in the comparison of performance outcomes by rival companies [65].

The systematic analysis of the environmental impact assessment can be illustrated by means of the life cycle approach, which shows the multitude of effects of all the factors related to the environmental impact of a building's life cycle (see Figure 1) [66].

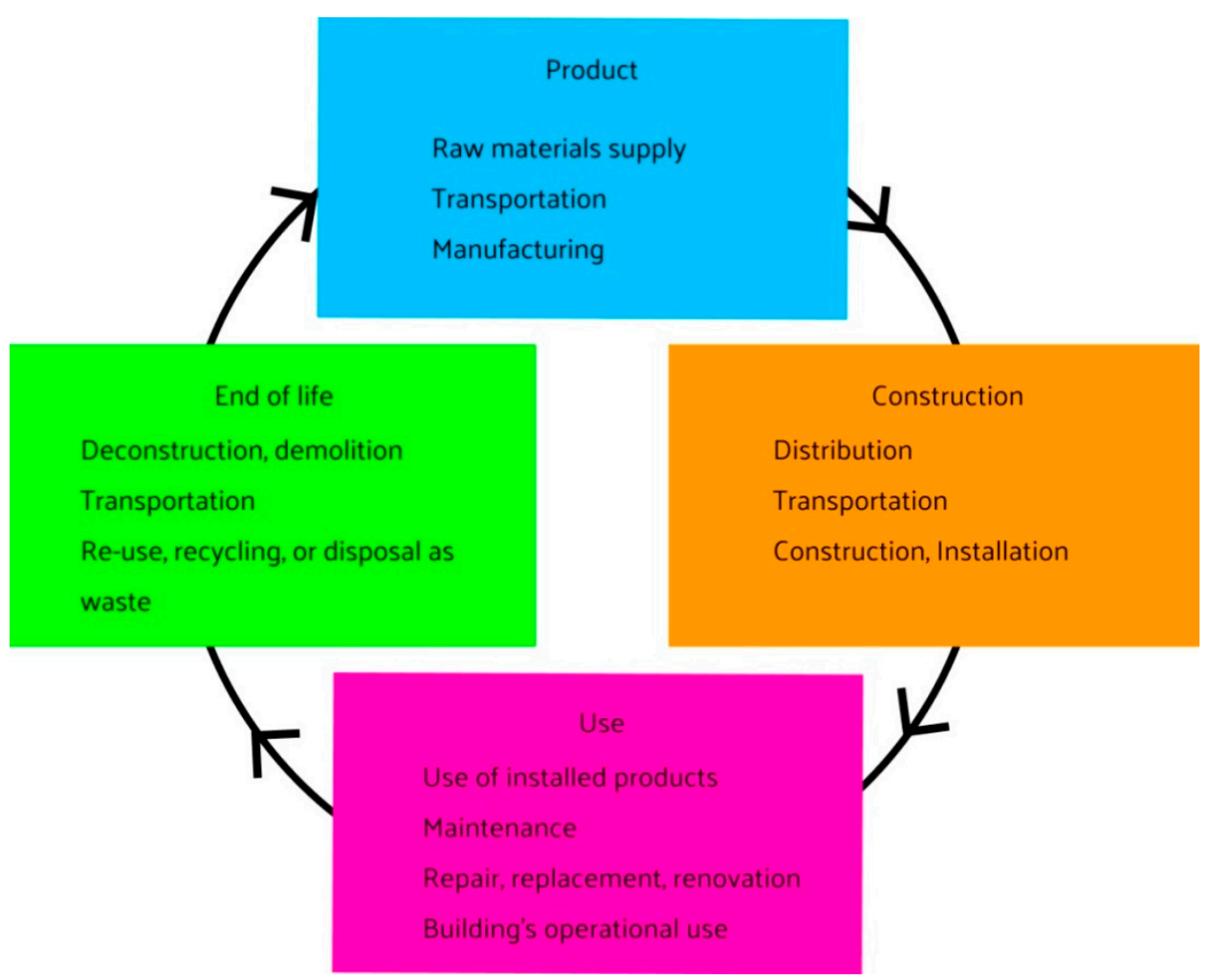

Figure 1. The life cycle of a building. 
The life cycle assessment (LCA) basically analyzes the emission of dangerous substances in the air, water, and soil, as well as the materials used throughout the building process. A building is a difficult outcome to be pinpointed, with a multidimensional use in just an individual unit. Moreover, the construction sector is a complex system of products with multiple functions, different users, and various life cycles (see Figure 2) [67]. LCA investigates the estimated impact of supplying raw materials in the process of construction, production, use, and finally, disposal.

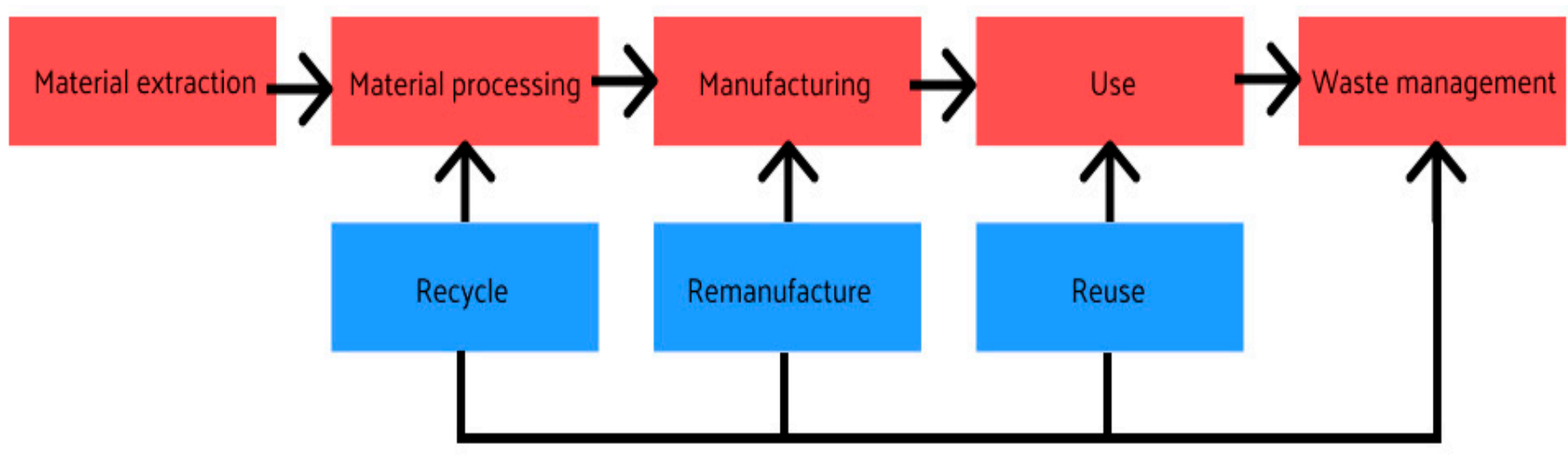

Figure 2. The life cycle of a building viewed as a horizontal process.

The LCA method shows how the consumption of energy in a supply chain plays a crucial role in the total environmental performance of the suggested approach, as well as the energy intensity of the specific technology used [68].

LCA studies range from quite basic to very complex depending on the number of elements that are analyzed, the complexity of the process that is investigated, and the type of impact factors that are taken into consideration.

The LCA analysis is an adequate method that can be used to assess the impact of a construction process on the environment. It offers the benefit of analyzing the complete process of energy usage, including the energy incorporated into the materials used [69-72].

According to industrial standards, an LCA includes four main phases: the definition of the goals, a life-cycle inventory, the life-cycle impact analysis, as well as the interpretation of results.

\section{Results}

Several specific factors must to be taken into account in order to develop a model for the responsible management of environmental resources by a construction company.

Firstly, the potential opportunities and threats of choosing a certain building technology need to be identified. Secondly, the suitable technological capabilities of the specific construction company have to be assessed. Finally, the acquisition of the building technologies and materials from local or foreign suppliers and their usage, are characteristic elements required for a proper strategic management of environmental resources [73].

The most frequently occurring environmental aspects are grouped in Table 1, according to the operating conditions prevailing on a specific building site and the environmental impact they generate $[74,75]$. 
Table 1. List of centralized environmental aspects and significant environmental impact factors.

\begin{tabular}{|c|c|c|c|c|c|c|}
\hline Criteria & \multicolumn{6}{|c|}{ Score and Interpretation } \\
\hline $\begin{array}{l}\text { 1. Size/magnitude } \\
\text { impact }\end{array}$ & $\begin{array}{c}0 \\
\text { Minimal } \\
\text { can be fixed immediately }\end{array}$ & $\begin{array}{c}2 \\
\text { Small } \\
\text { short-term }\end{array}$ & $\begin{array}{c}4 \\
\text { Medium } \\
\text { lasting, reversible impact }\end{array}$ & $\begin{array}{c}6 \\
\text { Serious } \\
\text { significant } \\
\text { emission }\end{array}$ & $\begin{array}{c}8 \\
\text { Very serious } \\
\text { lasting environmental } \\
\text { damage }\end{array}$ & $\begin{array}{c}10 \\
\text { Extreme } \\
\text { puts human life directly } \\
\text { in danger }\end{array}$ \\
\hline \multicolumn{7}{|c|}{ Control threshold: 2; greater than 2 means environmental impact } \\
\hline $\begin{array}{l}\text { 2. The frequency of } \\
\text { occurrence }\end{array}$ & $\begin{array}{c}0 \\
\text { Unlikely } \\
\text { measured in decades, } \\
\text { can only occur in } \\
\text { very special conditions }\end{array}$ & $\begin{array}{c}1 \\
\text { Very rare greater than } \\
\text { once a year, can appear } \\
\text { in case of serious } \\
\text { irregularities }\end{array}$ & $\begin{array}{c}2 \\
\text { Rare } \\
\text { once a year }\end{array}$ & $\begin{array}{c}3 \\
\text { Occasional } \\
\text { once per month }\end{array}$ & $\begin{array}{c}5 \\
\text { Periodic } \\
\text { once per } \\
\text { week }\end{array}$ & $\begin{array}{c}6 \\
\text { Permanent } \\
\text { daily, accompanies } \\
\text { normal operation }\end{array}$ \\
\hline \multicolumn{7}{|c|}{ Control threshold: 2; greater than 2 means environmental impact } \\
\hline $\begin{array}{l}\text { 3.1 Emissions of harmful } \\
\text { substances in the air }\end{array}$ & $\begin{array}{c}0 \\
\text { Minimal } \\
\text { can be remedied } \\
\text { immediately }\end{array}$ & $\begin{array}{c}2 \\
\text { Reduced } \\
\text { short-term }\end{array}$ & $\begin{array}{c}4 \\
\text { Medium } \\
\text { lasting, reversible } \\
\text { impact }\end{array}$ & $\begin{array}{c}6 \\
\text { Serious } \\
\text { significant emission }\end{array}$ & $\begin{array}{c}8 \\
\text { Very serious } \\
\text { lasting, environmental } \\
\text { damage }\end{array}$ & $\begin{array}{c}10 \\
\text { Extreme }\end{array}$ \\
\hline $\begin{array}{l}\text { 3.2. Emissions of } \\
\text { harmful substances in } \\
\text { water }\end{array}$ & $\begin{array}{c}0 \\
\text { Minimal } \\
\text { can be remedied } \\
\text { immediately }\end{array}$ & $\begin{array}{c}2 \\
\text { Reduced } \\
\text { short-term }\end{array}$ & $\begin{array}{c}4 \\
\text { Medium lasting, } \\
\text { reversible } \\
\text { impact }\end{array}$ & $\begin{array}{c}6 \\
\text { Serious } \\
\text { significant emission }\end{array}$ & $\begin{array}{c}8 \\
\text { Very serious } \\
\text { lasting environmental } \\
\text { damage }\end{array}$ & $\begin{array}{c}10 \\
\text { Extreme }\end{array}$ \\
\hline $\begin{array}{l}\text { 3.3 Emissions of harmful } \\
\text { substances in the soil }\end{array}$ & $\begin{array}{c}0 \\
\text { Minimal } \\
\text { can be remedied } \\
\text { immediately }\end{array}$ & $\begin{array}{c}2 \\
\text { Reduced } \\
\text { short-term }\end{array}$ & $\begin{array}{c}4 \\
\text { Medium lasting, } \\
\text { reversible } \\
\text { impact }\end{array}$ & $\begin{array}{c}6 \\
\text { Serious } \\
\text { significant emission }\end{array}$ & $\begin{array}{c}8 \\
\text { Very serious } \\
\text { damage }\end{array}$ & $\begin{array}{c}10 \\
\text { Extreme }\end{array}$ \\
\hline $\begin{array}{l}\text { 3.4. Amount of resources } \\
\text { used }\end{array}$ & $\begin{array}{c}0 \\
\text { Minimal } \\
\text { can be remedied } \\
\text { immediately }\end{array}$ & $\begin{array}{c}2 \\
\text { Reduced } \\
\text { short-term }\end{array}$ & $\begin{array}{c}4 \\
\text { Medium } \\
\text { lasting }\end{array}$ & $\begin{array}{c}6 \\
\text { Serious } \\
\text { significant amount }\end{array}$ & $\begin{array}{c}8 \\
\text { Very serious } \\
\text { lasting damage to } \\
\text { environment }\end{array}$ & $\begin{array}{c}10 \\
\text { Extreme }\end{array}$ \\
\hline \multicolumn{7}{|c|}{ Control threshold: 2; greater than 2 means environmental impact } \\
\hline
\end{tabular}


Table 1. Cont.

\begin{tabular}{|c|c|c|c|c|c|c|}
\hline Criteria & \multicolumn{6}{|c|}{ Score and Interpretation } \\
\hline 4. Health risk & $\begin{array}{c}0 \\
\text { Minimal }\end{array}$ & $\begin{array}{c}2 \\
\text { Reduced }\end{array}$ & $\begin{array}{c}4 \\
\text { Medium }\end{array}$ & $\begin{array}{c}6 \\
\text { High }\end{array}$ & $\begin{array}{c}8 \\
\text { Very high }\end{array}$ & $\begin{array}{c}10 \\
\text { Extreme }\end{array}$ \\
\hline \multicolumn{7}{|c|}{ Control threshold: 2; greater than 2 means environmental impact } \\
\hline $\begin{array}{l}\text { 5. Predictability } \\
\text { of the impact (in the } \\
\text { initial stage) }\end{array}$ & $\begin{array}{c}0 \\
\text { Good } \\
\text { project well done, took in } \\
\text { account all } \\
\text { issues/green } \\
\text { construction }\end{array}$ & - & $\begin{array}{c}4 \\
\text { Medium } \\
\text { not all aspects were } \\
\text { considered }\end{array}$ & - & - & $\begin{array}{c}10 \\
\text { Poor } \\
\text { environmental aspects } \\
\text { have not been taken into } \\
\text { account }\end{array}$ \\
\hline \multicolumn{7}{|c|}{ Control threshold: 4 ; greater or equal to 4 means environmental impact } \\
\hline $\begin{array}{l}\text { 6. Compliance with } \\
\text { relevant legisla- } \\
\text { tion/standards/existence } \\
\text { of "stable values" }\end{array}$ & $\begin{array}{c}0 \\
\text { Good } \\
\text { compliance with } \\
\text { legislation and standards } \\
\text { in force }\end{array}$ & - & $\begin{array}{c}4 \\
\text { Medium } \\
\text { partial compliance/ } \\
\text { levels not covered }\end{array}$ & - & - & $\begin{array}{c}10 \\
\text { Non-compliance }\end{array}$ \\
\hline
\end{tabular}


The interpretation scale of these environmental aspects and the size of their environmental impact are assessed in Table 2.

Table 2. Interpretation scale for environmental impact factors.

\begin{tabular}{ccc}
\hline Criteria & Value & Impact Significance \\
\hline \multirow{2}{*}{$1,2,3.1-3.4$, and 4} & $<2$ & Insignificant impact on the environment \\
\cline { 2 - 3 } & $>2$ & Significant impact on the environment \\
\hline \multirow{2}{*}{5 and 6} & $<4$ & Insignificant impact on the environment \\
\cline { 2 - 3 } & $>4$ & Significant impact on the environment \\
\hline
\end{tabular}

Building projects have a profound impact on the environment at an international level. In fact, each aspect of a construction process creates adverse effects-from the mining activities used for the supply of materials, to the waste generated by the project and how the waste is finally disposed of. It is of paramount importance to acknowledge and take action to mitigate the environmental influence of building projects that harm the soil, the water, and the air surrounding us [76].

A short-structured questionnaire was used for a survey in order to determine and validate the share of various elements pegged to the environmental impact of construction. The researchers employed a non-probability sampling technique, which involves choosing a sample of persons who show availability and agree to answer the questions in the survey. The basis of the questionnaire was formed of seven elements of environmental impact carried by a construction, elements that were identified in a preparatory research. A total of 30 questionnaires were distributed to management representatives of Romanian building companies using online platforms.

The participants in the study were selected from the target group of building companies with their headquarters in Bucharest, Romania's capital city. Some 5070 building firms are listed in this category, most of them of small size. The research group that was approached for this study resulted from the snowball sampling technique. In such an approach, the authors referred to companies displaying similar features, meaning they were categorized in the 4120 National Registry Code for the construction of residential and nonresidential buildings, sometimes by means of recommendation from initial participants. In non-probability sampling, researchers are not trying to generate a representative sample. The strength of this research consists in getting in-depth information about the practical problems managers in the construction sector are facing when dealing with environmental aspects and the assessment of the environmental impact of their operations. This type of study also tries to identify latent, but relevant aspects to gain a deeper understanding of the research matter under investigation. However, from the 30 managers that took part in the survey, four of them represented large companies, eight of them medium companies, and eighteen of them small companies, all from Bucharest, thus the sample was fairly consistent with the distribution of building companies.

The respondents were asked to rank their views and attitudes according to a Likert scale, where 1 = very low effect, 2 = low effect, $3=$ neutral effect, $4=$ strong effect, and $5=$ very strong effect, for each environmental impact factor. The five-point scale was chosen to expand respondents' answers, which determines the weighting of each environmental impact factor. This approach aims to calculate the Relative Importance Index (RII) and to determine the rank of the environmental impact factors. The RII was used for the analysis due to its adequate function inside this research.

For determining this model, there are several means of calculation:

1. Using Mathematical Model (calculating the Standard Deviation, Relative Importance Index and then ranking according to values);

2. Using Excel formulas (STDEV, PRODUCT, RANK functions);

3. Using the SPSS software (computed application). 
The application of the mathematical model determined the use of two formulas described as follows:

- $\quad$ Standard deviation $(S)$ :

$$
S=\sqrt{\frac{\sum_{i-1}^{n}\left(X_{i}-\bar{X}\right)^{2}}{n}}
$$

where $X_{i}$-target value; $\bar{X}$-average; and $n$-total number of values.

- $\quad$ Relative Importance Index (RII):

$$
R I I=\sum_{i=0}^{n} \frac{W_{i}}{(A \times N)}
$$

where $W$-weight estimated for each statement by the respondents and ranges from minimum to maximum; while $A$-higher response integer; and $N$-total number of respondents.

In this case $W$ ranges from 1 to 5 , where 1 is the very low effect and 5 is the extremely strong effect, $A$ means the highest weight with value 5 , and $N$ means the total number of responses (30). The Relative Importance Index (RII) value range is from 0 to 1 and was calculated in Table 3. The aggregate overall index is the average of individual relative importance indexes of the specific elements indicated.

\begin{tabular}{|c|c|c|c|c|c|c|c|c|c|c|}
\hline \multirow{2}{*}{$\begin{array}{c}\text { Operating } \\
\text { Conditions/Environmental } \\
\text { Impact }\end{array}$} & \multicolumn{5}{|c|}{ Evaluation of Effects } & \multirow{2}{*}{ Total Responds } & \multirow{2}{*}{ Stand. Dev. (S) } & \multirow{2}{*}{ Weight } & \multirow{2}{*}{ RII } & \multirow{2}{*}{ Rank } \\
\hline & 5 & 4 & 3 & 2 & 1 & & & & & \\
\hline $\begin{array}{l}\text { Energy consumption/ } \\
\text { Resources consumption }\end{array}$ & 11 & 13 & 3 & 2 & 1 & 30 & 5.567764 & 121 & 0.807 & 3 \\
\hline $\begin{array}{c}\text { Fuel consumption/ } \\
\text { Resources consumption }\end{array}$ & 12 & 10 & 6 & 2 & 0 & 30 & 5.09902 & 122 & 0.813 & 2 \\
\hline $\begin{array}{l}\text { Emissions generation/ } \\
\text { Air pollution }\end{array}$ & 6 & 16 & 6 & 1 & 1 & 30 & 6.123724 & 115 & 0.767 & 5 \\
\hline $\begin{array}{l}\text { Generation of noise } \\
\text { and vibration/ } \\
\text { Noise pollution }\end{array}$ & 7 & 20 & 2 & 1 & 0 & 30 & 8.276473 & 123 & 0.820 & 1 \\
\hline $\begin{array}{l}\text { Accidental spills/ } \\
\text { Water pollution }\end{array}$ & 5 & 12 & 11 & 2 & 0 & 30 & 5.338539 & 110 & 0.733 & 6 \\
\hline $\begin{array}{l}\text { Fire generation/ } \\
\text { Soil pollution }\end{array}$ & 9 & 11 & 8 & 2 & 0 & 30 & 4.743416 & 117 & 0.780 & 4 \\
\hline $\begin{array}{l}\text { Effect on public/ } \\
\text { Health risk }\end{array}$ & 4 & 5 & 14 & 4 & 3 & 30 & 4.527693 & 93 & 0.620 & 7 \\
\hline
\end{tabular}

Table 3. Overall environmental impact of construction.

The responses collected during the survey form the basis for the weighting categories inside the model. The results of this study place "noise pollution" in the first position with $R I I=0.820$ in the respondents' options, as can be observed in Table 3 . The results might indicate the absence or the lack of enforcement of strict laws to curb noise or means that people living near construction sites are suffering from different sources of noise such as noise from transportation of materials; noise from building activities (e.g., excavation, backfill); loud noise from the use of building machinery (e.g., grinders, mixers).

Identifying the "noise pollution factor" as a weighted category is determined by the specifics found in most Romanian builders because they operate in urban areas. Although it seems surprising and different from other international surveys, where weighting is heavier on global warming, human health, or primary energy usage, the result is determined on 
the one hand by the Romanian construction market in continuous development, and on the other hand by way of horizontal construction compared to buildings with vertical potential.

As shown in the table of results (Table 3 ) the respondents ranked "resources consumption" in the second position with RII $=0.813$. This suggests that the consumption of resources is considered a factor with a very significant impact on the environment. This finding may be interpreted in the sense that the building activity requires a lot of raw materials, as well as fuel for transportation vehicles.

Also illustrated in Table 3, the respondents ranked "health risk" in the last position in their options with $R I I=0.620$. These results may be interpreted in the manner that building projects disturb the interests of the people, causing them social discomfort at home and at the office, when trying to sleep or perform various activities. Additionally, the exposure to dust, regardless of its cause, may create health problems.

The environmental aspects and the assessment of their associated impact are presented in Table 4. The operating conditions are ranked as Normal (n) or Emergency $(\mathrm{u})$. The green color indicates a low or insignificant impact on the environment, or stable operating conditions, where regulations and standards have been applied. These situations acknowledge a proper management of the environmental resources. The red color witnesses several emergencies where proper enforcement was lacking, so immediate actions need to be taken to mitigate the adverse effects on the environment. 
Table 4. Impact assessment of environmental aspects.

\begin{tabular}{|c|c|c|c|c|c|c|c|c|c|c|c|}
\hline \multirow[b]{2}{*}{$\begin{array}{l}\text { Operating } \\
\text { Conditions }\end{array}$} & \multirow[b]{2}{*}{$\begin{array}{c}\text { Environmental } \\
\text { Impact }\end{array}$} & \multicolumn{10}{|c|}{ Impact Assessment } \\
\hline & & $\begin{array}{l}\text { Size/Magnitude } \\
\text { of Impact }\end{array}$ & $\begin{array}{c}\text { Frequency of } \\
\text { Occurrence }\end{array}$ & $\begin{array}{l}\text { Emissions } \\
\text { of Harmful } \\
\text { Substances } \\
\text { in the Air }\end{array}$ & $\begin{array}{l}\text { Emissions } \\
\text { of Harmful } \\
\text { Substances } \\
\text { in the Water }\end{array}$ & $\begin{array}{l}\text { Emissions } \\
\text { of Harmful } \\
\text { Substances } \\
\text { in the Soil }\end{array}$ & $\begin{array}{c}\text { Amount } \\
\text { of Resources } \\
\text { Used }\end{array}$ & Healt & Risk & $\begin{array}{c}\text { Predictability } \\
\text { in Design } \\
\text { Phase }\end{array}$ & $\begin{array}{c}\text { Existence of } \\
\text { Stable } \\
\text { Values }\end{array}$ \\
\hline $\begin{array}{c}\text { Energy } \\
\text { consumption }\end{array}$ & $\mathrm{n}$ & $\begin{array}{c}\text { Resources } \\
\text { consumption }\end{array}$ & Medium & Periodic & Minimal & Minimal & Minimal & $\begin{array}{l}\text { Seri } \\
\text { ous }\end{array}$ & $\begin{array}{c}\text { Mini } \\
\text { mal }\end{array}$ & Good & Good \\
\hline Fuel consumption & $\mathrm{n}$ & $\begin{array}{l}\text { Resources } \\
\text { consumption }\end{array}$ & Medium & Permanent & Minimal & Minimal & Minimal & $\begin{array}{l}\text { Seri } \\
\text { ous }\end{array}$ & $\begin{array}{c}\text { Mini } \\
\text { mal }\end{array}$ & Good & Good \\
\hline $\begin{array}{l}\text { Emissions } \\
\text { generation }\end{array}$ & $\mathrm{n}$ & Air pollution & Medium & Permanent & Serious & Minimal & Minimal & $\begin{array}{l}\text { Mini } \\
\text { mal }\end{array}$ & $\begin{array}{l}\text { Redu } \\
\text { ced }\end{array}$ & Good & Good \\
\hline $\begin{array}{l}\text { Generation of noise } \\
\text { and vibration }\end{array}$ & $\mathrm{n}$ & $\begin{array}{l}\text { Noise } \\
\text { pollution }\end{array}$ & Small & Periodic & Minimal & Minimal & Minimal & $\begin{array}{l}\text { Mini } \\
\text { mal }\end{array}$ & $\begin{array}{l}\text { Med } \\
\text { ium }\end{array}$ & Good & Good \\
\hline Accidental spills & $\mathrm{u}$ & $\begin{array}{l}\text { Soil, water, air } \\
\text { pollution }\end{array}$ & Serious & Very rare & Medium & Serious & Serious & $\begin{array}{c}\text { Mini } \\
\text { mal }\end{array}$ & High & Good & Good \\
\hline Fire generation & $\mathrm{u}$ & $\begin{array}{l}\text { Water, air, soil } \\
\text { pollution }\end{array}$ & Extreme & Very rare & Medium & Medium & Medium & $\begin{array}{c}\text { Mini } \\
\text { mal }\end{array}$ & $\begin{array}{l}\text { Extr } \\
\text { eme }\end{array}$ & Good & Good \\
\hline
\end{tabular}




\section{Discussion}

The environmental impact assessment model proposed in this research has some common elements with models and methods existing in the academic literature. The model suggested and applied in this study leans on life cycle assessment (LCA) models previously employed regarding the impact on the environment. The common elements are the consumption of resources and the air, noise, water, and soil pollution $[35,36]$.

The literature in the field abounds of papers presenting methods and case studies of buildings investigated from an LCA perspective $[2,34,37,50,52]$. However, only a minor part suggests practical tools such as tables and graphs available to managers as an orientation instrument when coordinating an ongoing building project. This study tries to fill at least partially this gap.

Compared to the environmental impact assessment stage of the existing LCA models, the model developed for this research has several advantages:

- It highlights the link between the existing operational conditions and their impact on the environment;

- It creates the possibility of unitary environmental impact assessment using a unitary measurement scale for different types of impact;

- It allows a faster ranking of the various operational risks on the environment;

- It can be integrated into the risk analysis methods and techniques at the construction project level (it can be easily integrated into the probability-impact matrix and in the risk map);

- It constitutes an instrument of management of the environmental resources that can be quickly implemented at the level of the company's specific processes using the transfer of managerial know-how;

- It is relatively simple and easy to assimilate for the personnel of the organization through organizational learning processes;

- It is suitable for taking over and adapting it to a specific software product, customizable to the needs of each organization from the construction sector.

The model proposed in this research is usable at the microeconomic level instead of other models in the literature, which are focused on macroeconomic issues [24]. However, it can be adapted and replicated to the macroeconomic level through a summative approach.

Although it does not fully incorporate the elements mentioned by other authors in the literature regarding the need to reconfigure business processes [25-28], the proposed model creates the conditions for reshaping existing business models and processes as a result of the impact of changing the models for the usage of environmental resources.

\section{Conclusions}

Construction is one of the areas that has a major impact on the environment, especially through pollution, energy consumption, and waste. That is why a series of models of responsibility analysis and management of environmental resources in the construction sector have been used in the literature. Most of these are based on life cycle assessment (LCA) models or on specific corporate social responsibility (CSR) models that integrate environmental resources. The model proposed in this research can be applied for environmental assessment in construction at the microeconomic level, as well as at the macroeconomic level, using a summative approach.

In this model, the impact assessment of environmental aspects uses emissions of harmful substances in the air, in the water, in the soil, health risk, predictability in the design phase, and the existence of stable values.

By applying this model of responsible management, the preconditions for reconfiguring operational conditions and processes with significant impact on the use of resources within construction projects can be created at the organizational level:

- Identification of resources in the design phase;

- Cost calculation and project budgeting; 
- Identification of the resource constraints that appear when the project is scheduled;

- Allocation and leveling of resources at project level;

- The specific reports of earned value.

Concerning the operational management process inside the construction company, an essential point is that members of the staff should be regularly informed and trained about various environmental problems and how they can recognize such issues to communicate these quickly to executives. They also need to be aware of individual responsibilities for environmental protection and the consequences of non-compliance. Furthermore, an important strategic aspect for a construction company is its relationship with stakeholders, such as suppliers, customers, business partners, the surrounding community, and environmental authorities, to ensure an efficient communication process and avoid pitfalls related to environmental issues that the building operations might cause. Under the care of the project manager, a quarterly executive summary will be prepared, including aspects concerning health, safety assurance, minor and major incidents, waste management records, pollution, generation of noise and vibration, in order to take immediate actions and prevent the recurrence of the negative impact, once occurred.

The strategic management of environmental resources is typically related to the cost-time relationship. In the short-term, costs can be considered as being low while in the long-term their amount might register higher values. The particular model applied in this research did not intend to integrate environmental problems into the cost-time relationship as other models in the specialized literature. Still, its influence on the two parameters is obvious if we consider the above mentioned issues. Given this limitation of the present study, the authors aim to develop the model further in their future research, to incorporate new variables and assess their influence, such as the costs associated. Using a quantitative research method will facilitate the extension of results. By applying the model in other contexts and countries, the approach opens up some appealing directions for future comparative research.

A vital point is that this model is scalable for its application in businesses in the building sector in different phases throughout the life cycle of a construction project. The results obtained can help decision-makers and practitioners to develop policies and interventions that ensure that all companies, regardless of their characteristics, contribute to environmental sustainability.

Author Contributions: Conceptualization, I.-S.V., M.N., O.C., V.R., C.-P.S. and N.M.; methodology, I.-S.V., M.N., O.C., V.R., C.-P.S. and N.M.; software, I.-S.V., M.N., O.C., V.R., C.-P.S. and N.M.; validation, I.-S.V., M.N., O.C., V.R., C.-P.S. and N.M.; formal analysis, I.-S.V., M.N., O.C., V.R., C.-P.S. and N.M.; investigation, I.-S.V., M.N., O.C., V.R., C.-P.S. and N.M.; resources, I.-S.V., M.N., O.C., V.R., C.-P.S. and N.M.; data curation, I.-S.V., M.N., O.C., V.R., C.-P.S. and N.M.; writing-original draft preparation, I.-S.V., M.N., O.C., V.R., C.-P.S. and N.M.; writing-review and editing, I.-S.V., M.N., O.C., V.R., C.-P.S. and N.M.; visualization, I.-S.V., M.N., O.C., V.R., C.-P.S. and N.M.; supervision, I.-S.V., M.N., O.C., V.R., C.-P.S. and N.M.; project administration, I.-S.V., M.N., O.C., V.R., C.-P.S. and N.M.; funding acquisition, I.-S.V., M.N., O.C., V.R., C.-P.S. and N.M. All authors have read and agreed to the published version of the manuscript.

Funding: This research received no external funding.

Institutional Review Board Statement: The study was conducted according to the guidelines of the Declaration of Helsinki, and follows the guidelines of the Romanian Law of National Education no. 1/ 2011 (article no. 124c, date of publication: 10 January 2011).

Informed Consent Statement: Informed consent was obtained from all subjects involved in the study.

Data Availability Statement: No issue, all data is in the public domain.

Conflicts of Interest: The authors declare no conflict of interest. 


\section{References}

1. Shen, L.Y.; Lu, W.S.; Yao, H.; Wu, D.H. A computer-based scoring method for measuring the environmental performance of construction activities. Autom. Constr. 2005, 14, 297-309. [CrossRef]

2. Khasreen, M.M.; Banfill, P.F.G.; Menzies, G.F. Life-Cycle Assessment and the Environmental Impact of Buildings: A review. Sustainability 2009, 1, 674-701. [CrossRef]

3. Probert, A.J.; Miller, A.; Ip, K.; Beckett, K.P.; Schofield, R. Accounting for the Life Cycle Carbon Emissions of New Dwellings in the UK. In Proceedings of the 12th International Conference on Nonconventional Materials and Technologies, Cairo, Egypt, 21-23 September 2010.

4. Chen, Z.; Li, H.; Wong, C.T.C. Environmental Management of Urban Construction Projects in China. J. Constr. Eng. Manag. 2000, 126, 320-324. [CrossRef]

5. Fuertes, A.; Casals, M.; Gangolells, M.; Forcada, N.; Macarulla, M.; Roca, X. An Environmental Impact Causal Model for improving the environmental performance of construction processes. J. Clean. Prod. 2013, 52, 425-437. [CrossRef]

6. Tam, V.W.Y.; Tam, C.M.; Zeng, S.X.; Chan, K.K. Environmental performance measurement indicators in construction. Build. Environ. 2006, 41, 164-173. [CrossRef]

7. Chang, Y.; Ries, R.J.; Wang, Y. The quantification of the embodied impacts of construction projects on energy, environment, and society based on I-O LCA. Energy Policy 2011, 39, 6321-6330. [CrossRef]

8. Eurostat. Energy, Transport and Environment Indicators; European Commission: Brussels, Belgium, 2010.

9. Tokbolat, S.; Nazipov, F.; Kim, J.R.; Karaca, F. Evaluation of the Environmental Performance of Residential Building Envelope Components. Energies 2020, 13, 174. [CrossRef]

10. Sartori, I.; Hestnes, A.G. Energy use in the life cycle of conventional and low-energy buildings: A review article. Energy Build. 2007, 39, 249-257. [CrossRef]

11. Optis, M.; Wild, P. Inadequate documentation in published life cycle energy reports on buildings. Int. J. Life Cycle Assess. 2010, 15, 644-651. [CrossRef]

12. Tan, Q.; Wen, Z.; Chen, J. The relationships between industrial pollution intensity and economic growth based on intensity environment Kuznets curve: Study on China's pilot cities. Int. J. Sustain. Dev. World Ecol. 2015, 22, 231-241. [CrossRef]

13. Shang, J.Q. Protection, Pollution Prevention and Control of Environment in Construction Stage. Mar. Geores. Geotech. 2003, 21, 227-235. [CrossRef]

14. Ofori, G. The environment: The fourth construction project objective? Constr. Manag. Econ. 1992, 10, 369-395. [CrossRef]

15. Loncar, D.; Paunkovic, J.; Jovanovic, V.; Krstic, V. Environmental and social responsibility of companies cross EU countries-Panel data analysis. Sci. Total Environ. 2019, 657, 287-296. [CrossRef]

16. Zeng, S.; Qin, Y.; Zeng, G. Impact of Corporate Environmental Responsibility on Investment Efficiency: The Moderating Roles of the Institutional Environment and Consumer Environmental Awareness. Sustainability 2019, 11, 4512. [CrossRef]

17. Koushki, P.A.; Kartam, N.; Al-Mutairi, N. Workers' perceptions and awareness of noise pollution at construction sites in Kuwait. Civ. Eng. Environ. Syst. 2004, 21, 127-136. [CrossRef]

18. Chen, R.H.; Chen, K.H. Control and Recovery of Environment after the Construction. Mar. Geores. Geotech. 2003, 21, 237-247. [CrossRef]

19. Chuangrong, M.; Xia, L.; Shugong, W.; Xingeng, C. Fringe View: Problems and Construction of Human Settlement Environment for "Village-in-City". Chin. J. Pop. Res. Environ. 2005, 3, 18-26. [CrossRef]

20. Chen, B.; Chen, J.; Zhao, J.; Zhang, F. Particulate Air Pollution from Combustion and Construction in Coastal and Urban Areas of China. J. Air Waste Manag. Assoc. 2011, 61, 1160-1165. [CrossRef]

21. Bota-Avram, C.; Grosanu, A.; Rachisan, P.R.; Ivan, O. Linking business environment education to auditing and financial reporting standards. A global perspective. J. Environ. Prot. Ecol. 2017, 18, 332-338.

22. Greenwood, L.; Rosenbeck, J.; Scott, J. The Role of the Environmental Manager in Advancing Environmental Sustainability and Social Responsibility in the Organization. J. Environ. Sust. 2012, 2, 59-73. [CrossRef]

23. Zolfagharian, S.; Nourbakhsh, M.; Irizarry, J.; Ressang, A.; Gheisari, M. Environmental Impacts Assessment on Construction Sites. In Proceedings of the Construction Research Congress, American Society of Civil Engineers, West Lafayette, IN, USA, 21-23 May 2012.

24. Bolognesi, T.; Nahrath, S. Environmental Governance Dynamics: Some Micro Foundations of Macro Failures. Ecol. Econ. 2020, 170, 1-30. [CrossRef]

25. Mokhlesian, S.; Holmen, M. Business model changes and green construction processes. Constr. Manag. Econ. 2012, 30, 761-775. [CrossRef]

26. Isik, Z.; Arditi, D.; Dikmen, I.; Birgonul, M.T. Impact of resources and strategies on construction company performance. J. Manag. Eng. 2010, 26, 9-18. [CrossRef]

27. Jang, Y.; Ahn, Y.; Park, M. Business Models and Performance of International Construction Companies. Sustainability 2019, 11, 2575. [CrossRef]

28. Chen, P.H.; Ong, C.F.; Hsu, S.C. The linkages between internationalization and environmental strategies of multinational construction firms. J. Clean. Prod. 2016, 116, 207-216. [CrossRef]

29. Shen, K.; Cheng, C.; Li, X.; Zhang, Z. Environmental Cost-Benefit Analysis of Prefabricated Public Housing in Beijing. Sustainability 2019, 11, 207. [CrossRef] 
30. Feng, K.; Lu, W.; Chen, S.; Wang, Y. An Integrated Environment-Cost-Time Optimisation Method for Construction Contractors Considering Global Warming. Sustainability 2018, 10, 4207. [CrossRef]

31. Ding, G.K.C. Sustainable Construction-The role of environmental assessment tools. J. Environ. Manag. 2008, 86, 451-464. [CrossRef] [PubMed]

32. Buyle, M.; Braet, J.; Audenaert, A. Life cycle assessment in the construction sector: A review. Renew. Sustain. Energy Rev. 2013, 26, 379-388. [CrossRef]

33. Heijungs, R.; Guinee, J.B.; Huppes, G. Environmental Life Cycle Assessment of Products: Guide and Backgrounds; CML: Leiden, The Netherlands, 1992.

34. Lindfors, L.G.; Christiansen, K.; Hoffman, L. Nordic Guidelines on Life-Cycle Assessment; Nord: Copenhagen, Denmark, 1995.

35. Ortiz, O.; Castells, F.; Sonnemann, G. Sustainability in the construction industry: A review of recent developments based on LCA. Constr. Build. Mat. 2009, 23, 28-39. [CrossRef]

36. Eun, J.; Son, J.; Moon, J.; Chung, J.S. Integration of life cycle assessment in the environmental information system. Int. J. Life Cycle Assess. 2009, 14, 364-373. [CrossRef]

37. Li, X.; Zhu, Y.; Zhang, Z. An LCA-based environmental impact assessment model for construction processes. Build. Environ. 2010, 45, 766-775. [CrossRef]

38. Bilec, M.; Ries, R.; Matthews, H.S.; Sharrard, A.L. Example of a Hybrid Life-Cycle Assessment of Construction Processes. J. Infrastruct. Syst. 2006, 12, 207-215. [CrossRef]

39. Sandanayake, M.; Zhang, G.; Setunge, S. A comparative method of air emission impact assessment for building construction activities. Environ. Impact Assess. Rev. 2018, 68, 1-9. [CrossRef]

40. Nazarko, L. Technology Assessment in Construction Sector as a Strategy towards Sustainability. Procedia Eng. 2015, 122, 290-295. [CrossRef]

41. Ozcan-Deniz, G.; Zhu, Y.; Ceron, V. Time, cost, and environmental impact analysis on construction operation optimization using genetic algorithms. J. Manag. Eng. 2011, 28, 265-272. [CrossRef]

42. Chegut, A.; Eichholtz, P.; Kok, N. The price of innovation: An analysis of the marginal cost of green buildings. J. Environ. Econ. Manag. 2019, 98,1-18. [CrossRef]

43. Li, S.; Liu, Y.; Purevjav, A.O.; Yang, L. Does subway expansion improve air quality? J. Environ. Econ. Manag. 2019, 96, 213-235. [CrossRef]

44. Fontao, E. The reality of spatial plans is delaying the growth of sustainable buildings. Energy Rep. 2020, 6, 38-43. [CrossRef]

45. Economic Commission for Europe. Spatial Planning Key Instrument for Development and Effective Governance with Special Reference to Countries in Transition; United Nations: New York, NY, USA; Geneva, Switzerland, 2008.

46. Borowczyk, J. Sustainable Urban Development: Spatial Analyses as Novel Tools for Planning a Universally Designed City. Sustainability 2018, 10, 1407. [CrossRef]

47. Crawford, J.; French, W. A low-carbon future: Spatial planning's role in enhancing technological innovation in the built environment. Energy Policy 2008, 36, 4575-4579. [CrossRef]

48. Xia, B.; Olanipekun, A.; Chen, Q.; Xie, L.Y. Conceptualising the state of the art of corporate social responsibility (CSR) in the construction industry and its nexus to sustainable development. J. Clean. Prod. 2018, 195, 340-353. [CrossRef]

49. Tiwari, V.K.; Verma, A.; Kumar, A.; Gupta, M. A Review on Environmental Impact Assessment of Construction Projects. J. Environ. Sci. Toxic. Food Tech. 2016, 10, 21-25.

50. Bayer, C.; Gamble, M.; Gentry, R.; Joshi, S. AIA Guide to Building Life Cycle Assessment in Practice; The American Institute of Architects: Washington, DC, USA, 2010.

51. Linnanen, L. Life cycle management: Integrated approach towards corporate environmental issues. Bus. Strategy Environ. 1995, 4, 117-127. [CrossRef]

52. Todor, R.D.; Hornet, M.H.; Iordan, N.F. Implementing the Life Cycle Cost Analysis in a Building Design. Adv. Eng. Forum 2017, 21, 581-586. [CrossRef]

53. Asdrubali, F.; Baldassarri, C.; Fthenakis, V. Life cycle analysis in the construction sector: Guiding the optimization of conventional Italian buildings. Energy Build. 2013, 64, 73-89. [CrossRef]

54. Sharma, A.; Saxena, A.; Sethi, M.; Shree, V.; Varun, G. Life cycle assessment of buildings: A review. Renew. Sustain. Energy Rev. 2011, 15, 871-875. [CrossRef]

55. Zabalza, I.; Scarpellini, S.; Aranda, A.; Llera, E.; Janez, A. Use of LCA as a Tool for Building Ecodesign. A Case Study of a Low Energy Building in Spain. Energies 2013, 6, 3901-3921. [CrossRef]

56. Borja, L.C.A.; Cesar, S.F.; Cunha, R.D.A.; Kiperstok, A. A Quantitative Method for Prediction of Environmental Aspects in Construction Sites of Residential Buildings. Sustainability 2018, 10, 1870. [CrossRef]

57. Gangolells, M.; Casals, M.; Forcada, N.; Fuertes, A.; Roca, X. Model for Enhancing Integrated Identification, Assessment, and Operational Control of On-Site Environmental Impacts and Health and Safety Risks in Construction Firms. J. Constr. Eng. Manag. 2013, 138-147. [CrossRef]

58. Rothbucher Thomas, N.I.; Bastos, C.D. Adoption of environmental practices on construction sites. Amb. Constr. 2017, 17, 1678-8621. [CrossRef]

59. Irizarry, J.; Zolfagharian, S.; Nourbakhsh, M.; Jusoff, K.; Zakaria, R. The development of a sustainable-construction planning system. J. Inf. Technol. Constr. 2012, 17, 1874-4753. 
60. Gangolells, M.; Casals, M.; Gasso, S.; Forcada, N.; Roca, X.; Fuertes, A. Assessing concerns of interested parties when predicting the significance of environmental impacts related to the construction process of residential buildings. Build. Environ. 2011, 46, 1023-1037. [CrossRef]

61. Kilbert, C.J. Sustainable Construction: Green Building Design and Delivery; John Wiley and Sons: London, UK, 2005.

62. Marzouk, M.; Azab, S. Environmental and economic impact assessment of construction and demolition waste disposal using system dynamics. Resour. Conserv. Recycl. 2013, 82, 41-49. [CrossRef]

63. Enshassi, A.; Kochendoerfer, B.; Rizq, E. An evaluation of environmental impacts of construction projects. Rev. Ing. Constr. 2014, 29, 234-254. [CrossRef]

64. Predescu, L.; Radu, F.; Tabirca, A.I. Needs of local sustainable development. Ann. Univ. Oradea Econ. Sci. 2011, 1,91-97.

65. Ivan, R.; Capusneanu, S.; Topor, D.; Oprea, D.M. Environmental Economics Auditing of Eco-Dashboard of a Company in Aluminum Industry and Its Impact on Sustainability. J. Environ. Prot. Ecol. 2017, 18, 399-409.

66. Manolescu, A. Managementul Resurselor Umane; Economica: Bucharest, Romania, 2003.

67. Moldovan, M. Ergonomie; Didactica and Pedagogica: Bucharest, Romania, 1993.

68. Zanni, S.; Cipolla, S.S.; di Fusco, E.; Lenci, A.; Altobelli, M.; Currado, A.; Maglionico, M.; Bonoli, A. Modeling for sustainability: Life cycle assessment application to evaluate environmental performance of water recycling solutions at the dwelling level. Sustain. Prod. Consum. 2019, 17, 47-61. [CrossRef]

69. Waters, T.R.; Putz-Anderson, V.; Garg, A.; Fine, L.J. Revised NIOSH equation for the design and evaluation of manual lifting tasks. Ergonomics 1993, 36, 749-776. [CrossRef] [PubMed]

70. Cornescu, V.; Mihailescu, I.; Stanciu, S. Management; Actami: Bucharest, Romania, 1994.

71. Varga, M.; Dragomir, C. Sustainable development-Shaken by the present economic-financial world crisis. Sibiu Alma Mater Univ. J. 2011, 4, 16-20.

72. Vlasceanu, M. Organizatii si Comportament Organizational; Polirom: Iasi, Romania, 2003.

73. Yilmaz, M.; Bakis, A. Sustainability in Construction Sector. Procedia Soc. Behav. Sci. 2015, 195, 2253-2262. [CrossRef]

74. Ciobotaru, V.; Frasineanu, C.; Frasineanu, I.; Tapurica, O.C. Politici Ecologice de Mediu; Economica: Bucharest, Romania, 2011.

75. Stavins, R. Economics of the Environment; Edward Elgar Publishing: Cheltenham, UK, 2019.

76. Dima, I.C.; Starostka-Patyk, M.; Radu, F. Logistics Costs Estimation in Case of Industrial Waste Management. In Proceedings of the 5th WSEAS International Conference on Renewable Energy Sources, Alexandru Ioan Cuza University of Iasi, Iasi, Romania, 1-3 July 2011. 